Zein, et al/Jurnal Ekonomi Syariah Teori dan Terapan Vol. 6 No. 1 Januari 2019: 15-22; PENGARUH PEMBIAYAAN DANA MUDHARABAH DALAM MENSEJAHTERAKAN PARA NASABAH UMKM BERDASARKAN PERSPEKTIF MAQASHID SYARIAH

\title{
PENGARUH PEMBIAYAAN DANA MUDHARABAH DALAM MENSEJAHTERAKAN PARA NASABAH UMKM BERDASARKAN PERSPEKTIF MAQASHID SYARIAH
}

\author{
Hilmy Zein \\ Departemen Ekonomi Syariah-Fakultas Ekonomi dan Bisnis-Universitas Airlangga \\ Email: hilmyzein@gmail.com \\ Sri Herianingrum \\ Departemen Ekonomi Syariah-Fakultas Ekonomi dan Bisnis-Universitas Airlangga \\ Email: sriheria@gmail.com
}

\begin{abstract}
:
This study aims to examine the effect of mudharabah funding on the welfare of customers of Micro, Small and Medium Enterprises (MSMEs) based on Maqashid Syariah with the variables of religion (ad-din), soul (an-nafs), sense (al-aql), offspring (an-nasl) and treasure (al-maal). The sample of this study is customers of mudharabah financing of Bank Jatim Syariah Merr Surabaya as many as 51 respondents. The data used are primary data collected using questionnaires distributed directly to the customers of MSMEs. Indicators of research variables are measured using Likert scales from 1 to 5 . This research proves that mudharabah funding have a significant positive effect on the welfare of customers based on maqashid sharia with the variables of religion (ad-din), soul (an-nafs), sense (al-aql) and treasure (al-maal). However, on offspring variable (an-nasl), the result indicates a significant negative effect.
\end{abstract}

Keywords: Mudharabah fund financing, Maqashid Syariah "ad-din, an-nafs, al-aql, an-nasl \& al-maal.

\section{PENDAHULUAN}

Usaha mikro, kecil dan menengah (UMKM) memiliki potensi yang besar untuk mendukung peningkatan produktivitas penyediaan lapangan kerja yang lebih luas dan peningkatan kesejahteraan bagi masyarakat. Dalam perkembangannya, UMKM menghadapi berbagai macam persoalan yang berat karena adanya persaingan ketat, apalagi dengan masuknya produk-produk luar negeri (Hamid dan Susilo, 201 1:46).

Indonesia memiliki beberapa provinsi yang unggul di sektor perdagangan. Salah satu provinsi yang potensial untuk dikembangkan perdagangannya adalah Jawa Timur dengan 38 kota / kabupaten yang memiliki letak strategis dalam perdagangan. Jumlah usaha kecil, mikro 1) Jurnal ini merupakan bagian dari skripsi Hilmy Zein, NIM: 041211432012, yang diuji pada tanggal 25 Juni 2019.

dan menengah (UMKM) di Jawa Timur, berdasarkan survey yang dilakukan oleh Badan Pusat Statistik Provinsi Jawa Timur dalam website www.jatim.bps.go.id hingga akhir tahun 2016 mencapai 12,1 juta UMKM. Angka tersebut menunjukkan besarnya potensi UMKM di provinsi Jawa Timur yang jika bisa dikelola dengan baik akan mampu meningkatkan kesejahteraan para pelakU UMKM tersebut dan untuk kota Surabaya sendiri menurut survey Badan Pusat Statistik pada akhir taun 2016 angkanya mencapai 181 ribu usaha kecil, mikro dan menengah (UMKM) yang tersebar di seluruh wilayah di kota Surabaya (www.jatim.bps.go.id).

Bank Syariah sebagai sebuah lembaga kevangan pada dasaranya melakukan kegiatan meliputi 
Zein, et al/Jurnal Ekonomi Syariah Teori dan Terapan Vol. 6 No. 1 Januari 2019: 15-22; PENGARUH PEMBIAYAAN DANA MUDHARABAH DALAM MENSEJAHTERAKAN PARA NASABAH UMKM BERDASARKAN PERSPEKTIF MAQASHID SYARIAH

menghimpun, memberikan pembiayaan dan memberikan pelayanan jasa keuangan lainnya (Karim, 2014 : 255). Bank Syariah menjalankan kegiatan usahanya berdasarkan prinsip syariah dan menjauhi praktik riba, untuk diisi dengan kegiatan investasi atas dasar bagi hasil dari pembiayaan perdagangan. Industri perbankan syariah merupakan bagian dari sistem perbankan nasional yang mempunyai peranan penting dalam perekonomian. Peranan perbankan syariah secara khusus antara lain sebagai perekat nasionalisme baru, artinya menjadi fasilitator jaringan usaha ekonomi kerakyatan, memberdayakan ekonomi umat, mendorong penurunan spekulasi di pasar kevangan, mendorong pemerataan pendapatan, dan peningkatan efisiensi mobilitas dana (Muhamad, 2005:16).

Perbankan syariah sebagai bagian dari sistem perbankan nasional mempunyai peranan penting dalam perekonomian, Peranan perbankan syariah dalam aktivitas ekonomi Indonesia tidak jauh berbeda dengan perbankan konvensional. Perbedaan mendasar antara keduanya terletak pada prinsip-prinsip dalam transaksi keuangan atau operasional. Salah satu prinsip dalam operasional perbankan syariah adalah penerapan bagi hasil dan resiko (mahbub, 2016). Dalam memberikan bantuan pinjaman mudharabah cukup selektif dalam memilih nasabah karena tidak semua nasabah bisa diberi bantuan pembiayaan, Mengingat Mudharabah merupakan fasilitas untuk usaha mikro. sesuai dengan dalil dalam al Qur'an surat al Baqarah ayat 245,

Artinya: Siapakah yang mau memberi pinjaman kepada Allah, pinjaman yang baik (menafkahkan hartanya di jalan Allah), Maka Allah akan melipat gandakan pembayaran kepadanya dengan lipat ganda yang banyak dan Allah menyempitkan dan melapangkan (rezki) dan kepada-Nya-lah kamu dikembalikan (Al baqarah;245).

\section{LANDASAN TEORI DAN PENGEMBANGAN HIPOTESIS}

Menurut Undang-Undang Nomor 11 Tahun 2009, kesejahteraan adalah kondisi terpenuhinya kebutuhan material, spiritual, dan sosial warga masyarakat agar dapat hidup yang layak.Konsep kesejahteraan menurut Nasikun (1996:78) dapat dirumuskan sebagai padanan makna dari konsep martabat manusia yang dapat dilihat dari 4 indikator, yaitu : 1. Rasa aman (security), 2. Kesejahteraan (welfare), 3. Kebebasan (freedom), dan 4. Jati diri (identity). Todaro (2003:34) mengemukakan bahwa kesejahteraan masyarakat menengah ke bawah dapat direpresentasikan dari tingkat hidup masyarakat.Tingkat hidup masyarakat ditandai dengan berkurangnya tingkat kemiskinan, tingkat kesehatan yang lebih baik, perolehan tingkat pendidikan yang lebih tinggi, dan tingkat produktivitas masyarakat.

\section{Kesejahteraan dalam Perspektif Islam}

Dalam prinsip Islam, kesejahteraan bukan semata ditentukan oleh materi dan 
Zein, et al/Jurnal Ekonomi Syariah Teori dan Terapan Vol. 6 No. 1 Januari 2019: 15-22; PENGARUH PEMBIAYAAN DANA MUDHARABAH DALAM MENSEJAHTERAKAN PARA NASABAH UMKM BERDASARKAN PERSPEKTIF MAQASHID SYARIAH

tidak hanya milik seseorang atau keluarga tertentu, tetapi juga untuk orang lain secara menyeluruh. Islam sebagai agama yang rahmatan lil alamin, selain mengajarkan pemeluknya kepada pemenuhan kebutuhan non-materi berupa spiritualitas, juga mengajarkan tuntunan pemenuhan kebutuhan materi (ekonomi). Untuk mencapai tujuan hidup yang sejahtera, ada tiga hal pokok yang dapat dipahami dari ajaran Islam, yaitu tujuan hidup adalah kemenangan, kemanfaatan, dan permasalahan dalam pencapaiannya (Karim, 2001:2).

Pokok ketiga tersebut adalah permasalahan dari pencapaian falah yang melahirkan maslahah. Hal ini terjadi karena dalam pencapaian falah, manusia dibatasi oleh faktor kelemahan dan keterbatasan kemampuan, yang dalam ekonomi disebut dengan kelangkaan. Alam semesta yang tercipta dengan keterbatasan ini membuka peluang kelangkaan karena ketidakmerataan distribusi sumber daya, keterbatasan sumber daya manusia (Karim, 2001:9).

Islam merupakan ajaran yang sangat peduli terhadap kesejahteraan. Kesejahteraan dalam Islam pada intinya mencakup dua hal yaitu kesejahteraan di dunia dan di akhirat (Herianingrum,2014). Hal yang menjadi landasan dasar indikator kesejahteraan dalam Islam adalah bahwa setiap individu dalam Islam harus memperoleh perlindungan terhadap lima hal yang biasa disebut dengan mashlahah.
Menurut Al-Syatibi, mashlahah dasar bagi manusia terdiri dari agama (din), jiwa (nafs), akal (aql), keturunan (nasl), dan Harta (maal), Kelima mashlahah tersebut dapat dijadikan sebagai indikator kesejahteraan secara Islami. Selain itu, kelima hal ini merupakan satu kesatuan yang lengkap dalam kehidupan manusia.Penjelasan mengenai kelima kebutuhan dasar tersebut (agama, jiwa, akal, keturunan, dan harta) Kerangka konseptual penelitian ini dikembangkan berdasarkan pengaruh pembiayaan dana mudharabah kepada nasabah Umkm yang diukur dengan menggunakan indikator kesejahteraan islam dalam perspektif maqashid syariah

Kerangka konseptual penelitian ini adalah sebaaai berikut :

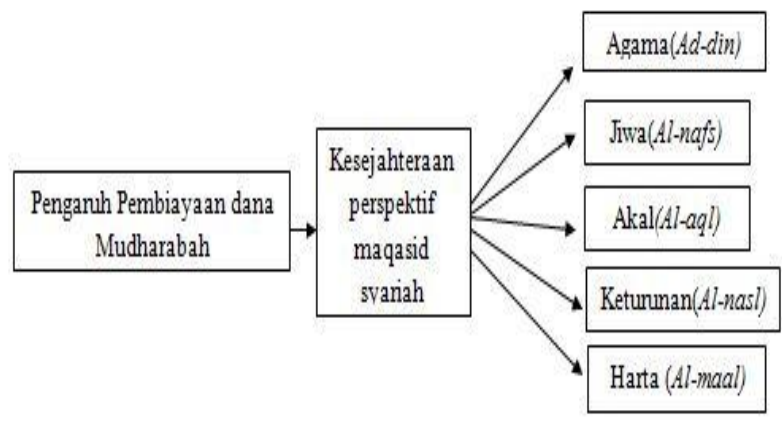

Gambar 1. Kerangka Konseptual

Pengaruh Pembiayaan dana Mudharabah terhadap Kesejahteraan dalam perspektif maqasid syariah dengan variabel Agama (Ad-din). Hal tersebut dapat disimpulkan apabila nasabah mendapatkan pembiayaan dana mudharabah maka pendapatan nasabah tersebut akan meningkat, hal ini berpengaruh terhadap peningkatan pembayaran zakat infak dan shodaqoh. 
Zein, et al/Jurnal Ekonomi Syariah Teori dan Terapan Vol. 6 No. 1 Januari 2019: 15-22; PENGARUH PEMBIAYAAN DANA MUDHARABAH DALAM MENSEJAHTERAKAN PARA NASABAH UMKM BERDASARKAN PERSPEKTIF MAQASHID SYARIAH

Pengaruh Pembiayaan dana Mudharabah terhadap Kesejahteraan dalam perspektif maqasid syariah dengan variabel Jiwa (Al-nafs). apabila nasabah mendapat pembiayaan dana mudharabah maka nasabah akan lebih menjaga eksistensi jiwa dengan cara menjaga tingkat kesehatan.

Pengaruh Pembiayaan dana Mudharabah terhadap Kesejahteraan dalam perspektif maqasid syariah dengan variabel Akal (Al-aql). apabila nasabah mendapatkan pembiayaan dana mudharabah untuk hal yang produktif maka para nasabah yang mendapatkan pembiayaan dana mudharabah akan

Pengaruh Pembiayaan dana Mudharabah terhadap Kesejahteraan dalam perspektif maqasid syariah dengan variabel Keturunan (Al-nasl). apabila nasabah mendapatkan pembiayaan dana mudharabah maka pendapatan nasabah tersebut akan meningkat, hal ini berpengaruh terhadap peningkatan pendidikan anak.

Pengaruh Pembiayaan dana Mudharabah terhadap Kesejahteraan dalam perspektif maqasid syariah dengan variabel Harta (Al-maal) apabila nasabah mendapatkan pembiayaan dana mudharabah maka para nasabah akan mengatur strategi dalam meningkatkan pendapatan usaha mereka.

\section{METODE PENELITIAN}

Penelitian ini menggunakan pendekatan kuantitatif. Pendekatan kuantitatif digunakan untuk menjelaskan hubungan antara satu variabel dengan variabel lain didalam suatu penelitian. Penelitian ini bertujuan untuk menguji analisis pengaruh pembiayaan dana mudharabah terhadap kesejahteraan nasabah umkm pada Bank Jatim Syariah cabang pembantu Merr Surabaya. Penelitian ini dirancang untuk melakukan pengujian hipotesis yang dikembangkan berdasarkan teori dan riset terdahulu. Hasil riset ini akan menyimpulkan apakah variabel independen yaitu pembiayaan dana mudharabah berpengaruh terhadap variabel dependen yaitu kesejahteraan berdasarkan maqashid syariah yang diukur dari Agama (Ad-din), Jiwa (al-nafs), Akal (Al-aql), Keturunan (Alnasl) dan Harta (Al-maal). Dengan demikian pendekatan kuantitatif merupakan pendekatan yang sesuai pada penelitian ini.

\section{HASIL DAN PEMBAHASAN}

Sejarah singkat tentang berdirinya Bank Jatim Unit Syariah (BJS) berdiri pada tanggal 4 April 2007 berdasarkan surat Bank Indonesia Nomor 9/75/DS/SB: perihal tentang persetujuan prinsip pendirian Unit Usaha Syariah (UUS), pembukaan kantor cabang syariah dan anggota dewan pengawas syariah yang berdasarkan surat Bank Indonesia Nomor 9/148/DPIP/SB tanggal 24 juli 2007 Dalam perjalanan mulai awal bank jatim syariah hingga 12 tahun hadir di tengah masyarakat dalam menghimpun, menyalurkan dan memberikan pelayanan perbankan lainnya, telah banyak melakukan pengembangan dan inovasi guna 
Zein, et al/Jurnal Ekonomi Syariah Teori dan Terapan Vol. 6 No. 1 Januari 2019: 15-22; PENGARUH PEMBIAYAAN DANA MUDHARABAH DALAM MENSEJAHTERAKAN PARA NASABAH UMKM BERDASARKAN PERSPEKTIF MAQASHID SYARIAH

memberikan kebutuhan yang terbaik menunjukkan jawaban responden kepada nasabah bank jatim syariah.

\section{Deskripsi hasil penelitian}

menyampaikan intepretasi statistik deskriptif, hasil pengujian validitas dan reliabilitas. Pada bagian ini juga disampaikan intepretasi hasil pengujian hipotesis penelitian.

\section{Statistik Deskriptif}

Tabel 1 Statistik Deskriptif menyampaikan data terkait dengan jawaban 51 responden tentang indikator. Indikator-indikator yang digunakan dalam penelitian ini. Indikator MD memiliki nilai minimal 1 dan nilai maximal 5 , sedangkan nilai mean 3,529 dan nilai SD 1,155. Hal ini menunjukkan bahwa jawaban responden tentang MD memiliki jawaban yang bervariasi karena nilai mean lebih besar dari nilai SD.

Nilai minimum indikator AG adalah 2 sedangkan nilai maximum 5. Mean indikator tersebut adalah sebesar 3,980 sedangkan standar deviasi (SD) sebesar 0,838. Hal ini menunjukkan jawaban responden tentang AG sangat bervariasi karena nilai SD lebih kecil dibandingkan mean.

Indikator JW memiliki nilai minimal 1 dan nilai maximal 5, sedangkan nilai mean 4,314 dan nilai SD 1,010. Hal ini menunjukkan bahwa jawaban responden tentang JW memiliki jawaban yang bervariasi karena nilai mean lebih besar dari nilai SD.

Indikator AK memiliki nilai minimal 2 sedangkan nilai maximal 5 sedangkan nilai mean 3,667 dan nilai SD 0,952. Hal ini

tentang AK sangat bervariasi karena nilai SD lebih kecil dibandingkan mean.

Indikator KT memiliki nilai minimal 2 dan nilai maximal 5, sedangkan mean 3,765 dan nilai SD 0,681. Hal ini menunjukkan jawaban responden tentang KT sangat bervariasi karena nilai mean lebih besar dari nilai SD.

Indikator HT memiliki nilai minimal 2 dan nilai maximal 5 , sedangkan nilai mean 3,725 dan nilai SD 0,874. Hal ini menunjukkan bahwa jawaban responden tentang HT memiliki jawaban yang bervariasi karena nilai mean lebih besar dari nilai SD.

\section{Tabel 1.}

Statistik Deskriptif Diringkas dirata-rata

\begin{tabular}{|c|c|c|c|c|c|c|}
\hline & 30 & Na & JW & $\Delta x$ & $\mathrm{KTT}$ & माT \\
\hline $\operatorname{san}$ & $t$ & 2 & $t$ & 2 & 2 & 2 \\
\hline $\operatorname{sen}$ & 5 & i & s & 5 & i & s \\
\hline SIE AN & 1,520 & 3,2000 & $43 * 4$ & 1,007 & 2708 & 2,72 \\
\hline $3 D$ & 1, 195 & 0,335 & 1000 & 0.282 & $Q, 085$ & 0.374 \\
\hline
\end{tabular}

\section{Hasil Pengujian Validitas}

Validitas Indikator menunjukkan bahwa semua indikator valid. Indikator dikatakan valid jika nilai loading lebih besar dari 0,8 dan nilai $P$ value lebih kecil dari 0,01 . Berikut merupakan tabel 2 hasil dari pengujian validitas :

Tabel 2.

Validitas Indikator

\begin{tabular}{|l|l|l|l|}
\hline Indikator & Loading & P Value & Valid \\
\hline MD & 1,000 & $<0,001$ & Valid \\
\hline AG & 1,000 & $<0,001$ & Valid \\
\hline JW & 1,000 & $<0,001$ & Valid \\
\hline AK & 1,000 & $<0,001$ & Valid \\
\hline KT & 1,000 & $<0,001$ & Valid \\
\hline HT & 1,000 & $<0,001$ & Valid \\
\hline
\end{tabular}


Zein, et al/Jurnal Ekonomi Syariah Teori dan Terapan Vol. 6 No. 1 Januari 2019: 15-22; PENGARUH PEMBIAYAAN DANA MUDHARABAH DALAM MENSEJAHTERAKAN PARA NASABAH UMKM BERDASARKAN PERSPEKTIF MAQASHID SYARIAH

\section{Hasil Pengujian Reliabilitas}

Hasil pengujian reliabilitas dapat dilihat pada tabel 3, yang menunjukkan semua variabel laten sudah reilabel. Hal ini ditunjukkan dengan nilai AVE dan Composite Reliability diatas 0,8 .

Tabel 3. Hasil Uji Reliabilitas

\begin{tabular}{|l|l|l|l|}
\hline $\begin{array}{l}\text { Variabel } \\
\text { Laten }\end{array}$ & AVE & $\begin{array}{l}\text { Composite } \\
\text { Reliability }\end{array}$ & Reliabilitas \\
\hline MD & 1,000 & 1,000 & Terpenuhi \\
\hline AG & 1,000 & 1,000 & Terpenuhi \\
\hline JW & 1,000 & 1,000 & Terpenuhi \\
\hline AK & 1,000 & 1,000 & Terpenuhi \\
\hline KT & 1,000 & 1,000 & Terpenuhi \\
\hline HT & 1,000 & 1,000 & Terpenuhi \\
\hline
\end{tabular}

\section{Hasil Pengujian Hipotesis}

Nilai koefisien $(\beta)=0,37$ dan nilai $\mathrm{P}<0,01$ menunjukkan bahwa $M D$ berpengaruh signifikan positif terhadap AG. Berdasarkan nilai koefisien positif dan $\mathrm{P}$ Value lebih kecil 5\%, maka $\mathrm{H} 1$ penelitian ini diterima. Hal ini berarti para nasabah pembiayaan dana mudharabah mengalami kesejahteraan setelah memperoleh dana tersebut sehingga berpengaruh terhadap kesejahteraan berdasarkan maqashid syariah dengan variabel agama. MD dapat menjelaskan AG sebesar $14 \%\left(R^{2}=0,14\right)$.

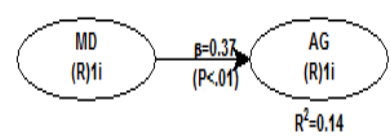

Gambar 2. Hasil Pengujian Pengaruh AG terhadap MD
Nilai koefisien $(\beta)=0,37$ dan nilai $\mathrm{P}<0,01$ menunjukkan bahwa $\mathrm{MD}$ berpengaruh signifikan positif terhadap JW. Berdasarkan nilai koefisien positif dan P Value lebih kecil 5\% maka H3. Penelitian ini diterima. Hal ini berarti para nasabah pembiayaan dana mudharabah mengalami kesejahteraan setelah memperoleh dana tersebut sehingga berpengaruh terhadap kesejahteraan berdasarkan maqashid syariah dengan variabel jiwa. MD dapat menjelaskan JW sebesar $13 \%\left(R^{2}=0.13\right)$.

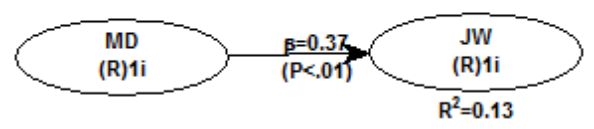

\section{Gambar 3. Hasil Pengujian Pengaruh MD} terhadap JW

Nilai koefisien $(\beta)=0,40$ dan nilai $\mathrm{P}=0,1$ menunjukkan bahwa $M D$ berpengaruh signifikan positif terhadap AK. Berdasarkan nilai koefisien positif dan $P$ Value lebih kecil 5\%, maka $\mathrm{H} 2$ penelitian ini diterima. Hal ini berarti para nasabah pembiayaan dana mudharabah mengalami kesejahteraan setelah memperoleh dana tersebut sehingga berpengaruh terhadap kesejahteraan berdasarkan maqashid syariah dengan variabel akal. MD dapat menjelaskan AK sebesar $16 \%\left(R^{2}=0,16\right)$.

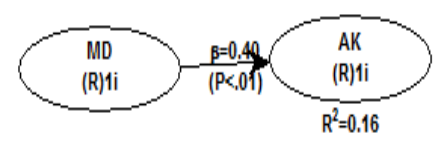

Gambar 4. Hasil Pengujian Pengaruh MD terhadap AK 
Zein, et al/Jurnal Ekonomi Syariah Teori dan Terapan Vol. 6 No. 1 Januari 2019: 15-22; PENGARUH PEMBIAYAAN DANA MUDHARABAH DALAM MENSEJAHTERAKAN PARA NASABAH UMKM BERDASARKAN PERSPEKTIF MAQASHID SYARIAH

Nilai koefisien $(\beta)=-0,14$ dan nilai

$\mathrm{P}=0.14$ menunjukkan bahwa $\mathrm{MD}$ berpengaruh signifikan negatif terhadap KT. Berdasarkan nilai koefisien negatif dan $\mathrm{P}$ Value lebih kecil 5\% maka $\mathrm{H} 4$ penelitian ini tidak diterima. Hal ini berarti para nasabah pembiayaan dana mudharabah tidak mengalami kesejahteraan setelah memperoleh dana tersebut sehingga tidak berpengaruh terhadap kesejahteraan berdasarkan maqashid syariah dengan variabel keturunan. MD dapat menjelaskan $K T$ sebesar $2 \%\left(R^{2}=0,2\right)$.

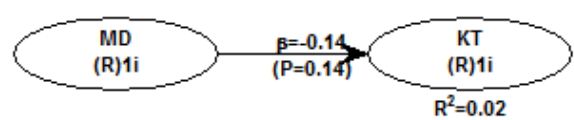

\section{Gambar 5. Hasil Pengujian Pengaruh MD terhadap KT}

Nilai koefisien $(\beta)=0,47$ dan nilai $\mathrm{P}<0.01$ menunjukkan bahwa $\mathrm{HT}$ berpengaruh signifikan positif terhadap MD. Berdasarkan nilai koefisien positif dan $\mathrm{P}$ Value lebih kecil 5\%, maka $\mathrm{H} 5$ penelitian ini diterima. Hal ini berarti para nasabah pembiayaan dana mudharabah mengalami kesejahteraan setelah memperoleh dana tersebut sehingga berpengaruh terhadap kesejahteraan berdasarkan maqashid syariah dengan variabel harta. MD dapat menjelaskan HT sebesar $22 \%\left(R^{2}=0,22\right)$.

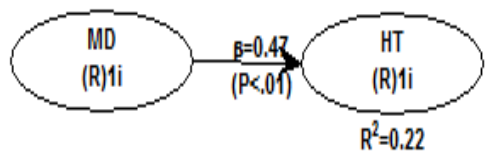

Gambar 6. Hasil Pengujian Pengaruh MD terhadap HT.
V. SIMPULAN

Berdasarkan hasil uji analisis menggunakan warp-pls 6.0 yang telah dilakukan atas variabel variabel yang di teliti, maka kesimpulan yang dapat diambil dari penelitian ini yaitu:

1. Pembiayaan dana mudharabah berpengaruh positif signifikan terhadap kesejahteraan nasabah berdasarkan maqashid syariah tentang variabel agama(ad-din).

2. Pembiayaan dana mudharabah berpengaruh positif signifikan terhadap kesejahteraan nasabah berdasarkan maqashid syariah tentang variabel jiwa(an-nafs).

3. Pembiayaan dana mudharabah berpengaruh positif signifikan terhadap kesejahteraan nasabah berdasarkan maqashid syariah tentang variabel akal (al-aql).

4. Pembiayaan dana mudharabah berpengaruh negatif signifikan terhadap kesejahteraan nasabah berdasarkan maqashid syariah tentang variabel keturunan (alnasl).

5. Pembiayaan dana mudharabah berpengaruh positif signifikan terhadap kesejahteraan nasabah berdasarkan maqashid syariah tentang variabel harta (al-maal).

\section{DAFTAR PUSTAKA}

Ascarya. 2007. Akad dan Produk Bank Syariah. Jakarta: PT Raja Grafindo Persada.

Ali, Hamdani. 1986. FilsafatPendidikan. Yogyakarta: Kota Kembang 
Zein, et al/Jurnal Ekonomi Syariah Teori dan Terapan Vol. 6 No. 1 Januari 2019: 15-22; PENGARUH PEMBIAYAAN DANA MUDHARABAH DALAM MENSEJAHTERAKAN PARA NASABAH UMKM BERDASARKAN PERSPEKTIF MAQASHID SYARIAH

Antonio, Muhammad Syafi'i. 2001. Bank Syariah dari Teori ke Praktik. Jakarta: Gemalnsani.

Abdullah Saeed, Bank Islam dan Bunga: Studi Kritis Larangan Riba dan Interpretasi Kontemporer, (Yogyakarta: Pustaka Pelajar, 2003), h. 91

Hendi Suhendi, 2002, Fiqih Muamalah, Raja grafindo persada, Jakarta, hlm.136.

http://jatim.bps.go.id/datastatistik/jawati murkotasurabaya.434766, Diakses Pada 17 Febuari 2019.

Http://ojk.go.id/id/kanal/iknb/Pages/Lem baga-Kevangansyariah, diakses pada 20 Januari 2019

Karim, Adiwarman. 2001. Ekonomi Islam, SuatuKajianKontemporer. Jakarta: Gemalnsani

Mujahidin, Akhmad, Ekonomi Islam: Sejarah, Konsep, Instrumen, Negara, dan Pasar, (Jakarta: Rajawali Pers, 2013), Cet- ke-2, h.257.

Muhammad, Akuntansi Bank syariah, (Yogyakarta: Trust Media, 2009), h. 56

Muhamad Syakir. 2004. Teknik PerhitunganBagi Hasil dan Profit Margin pada Bank Syariah. Yogyakarta: UII Press.

Tadjab. 1994. PerbandinganPendidikan. Surabaya: KaryaAbditama.

Todaro, Michael P. dan Stephen C. Smith.2003. Pembangunan Ekonomi di DuniaKetiga, edisikedelapan. Jakarta: Erlangga.
Undang-Undang Republik Indonesia No. 20 tahun 2008 pasal 1 dan 6 tentang Usaha Mikro, Kecil dan Menengah.

Undang-Undang Republik Indonesia No. 10 tahun 1998 tentang pengertian bank syariah.

Undang-Undang Republik Indonesia No. 11 tahun 2009 tentang kesejahteraan sosial dan kesejahteraan UMKM.

Undang-Undang Republik Indonesia No. 21 tahun 2008 tentang tugas lembaga kevangan syariah.

Undang-Undang Nomor 1 Tahun 2013 tentang Lembaga Kevangan Mikro. 